\title{
"JUNTAS ATRÁS DO SOL" E OUTROS CONTOS: A FEMININA VIAGEM DE DINA SALÚSTIO
}

\section{"TOGETHER BEHIND THE SUN" AND OTHER TALES: THE FEMININE JOURNEY OF DINA SALÚSTIO}

Cíntia Acosta Kütter ${ }^{1}$

A presença feminina na literatura produzida em Cabo Verde, revelada com mais rigor apenas após a independência em 1975, teve, como precursoras, escritoras como Iolanda Morazzo, Orlanda Amarílis e Margarida Mascarenhas. Hoje o nome que atravessa o Atlântico e ocupa o lugar de destaque dessa escrita no feminino é o de Dina Salústio (Bernardina de Oliveira Salústio), nascida em Santo Antão, arquipélago de Cabo Verde, em 1941. Sua produção literária passeia entre contos (Mornas eram as noites, de 1994), romances (A louca do serrano, 1998; Filhas do vento, 1999 e Veromar, 2019) e produção infanto-juvenil (Estrelinha tlim tlim, 1998; Que os olhos não vêem, 2002, em coautoria com Marilene Pereira), passando pela participação em antolologias (Mirabilis de veias ao sol: antologia dos novíssimos poetas cabo-verdianos - na qual desvendamos a faceta da poeta Dina Salústio -; Antologia do mar na poesia africana de língua portuguesa do século XX) e ensaios (Insularidade na literatura Cabo-verdiana).

Na obra Filhos de Deus (2018), seu trabalho contístico mais recente, a autora passeia pelos trinta e cinco contos que o compõem e apresenta ao leitor seus contemporâneos deslocamentos. A viagem pela obra se inicia por seus elementos paratextuais. Desse modo, figurado na capa do livro, o cais - uma das vias de acesso à ilha -, é apresentado ao leitor como o lugar daqueles que partem ou chegam, ou ainda um lugar de espera para aqueles que ficam. O livro se constrói a partir desse cais, presente no sentimento insular, mas pelo olhar engendrado das mulheres. Filhos de Deus possui quatro eixos temáticos que o subdividem: narrativas femininas; narrativas insulares; narrativas sobre o arquipélago e narrativas teórico-críticas. 
Em "Sapatos de verniz", a autora apresenta ao seu leitor a situação de uma mãe, "mulher do peixe", que se vê só e duramente magoada pela filha que prefere a "carona" da amiga para a formatura à companhia de sua mãe. E ao enfatizar "Não te esqueças de pôr o perfume que o tio mandou [...] O perfume, mãe! Não te esqueças!" (2018, p.15), a filha lembra duramente que a mãe cheira a peixe, por ser uma trabalhadora do cais, classe vista como inferior àquela que a filha, agora uma formanda, pensa que nela pertence. Já no conto "Filhos de Deus", a protagonista Nha Teodora, uma costureira, justifica a indagação da vizinha, Menininha, sobre a paternidade de seus filhos, justificando que estes são filhos de Deus. A crítica vinda a partir da voz da interlocutora aponta para um questionamento antigo em torno da figura divina e da humanidade que trata seus "filhos" de forma inumana. Ou seja: “Deus não tem filhos largados pelo mundo!” (2018, p.30). Dina Salústio aponta, para além da questão da mulher, a maternidade solo e o abandono parental, cujo único provento vem do ato de costurar de Nha Teodora, que, ao morrer, leva a narradora a se questionar se aquele "pai" tomaria conta daquelas crianças.

“Juntas atrás do sol”, por sua vez, inicia-se como um breve encontro entre amigas, mas vai além. A narrativa entre as três amigas vai dos encontros afetivos às gargalhadas e saudades que umas sentem das outras; passa pelas confidências sobre o divórcio e pela violência doméstica, sinalizada pela cicatriz do braço da amiga: "Como custava dizer do sofrimento! Como custa dizer da nossa intimidade magoada!” (2018, p.39). Em “Falsa fábula”, a dor sentida pelas mulheres e o abandono parental se fazem presentes ainda pela personagem-mãe, elíptica, que tenta preservar a figura paterna, Natal após Natal, à sua única filha. Esta sentia apenas ódio e indiferença, pois lembrava-se das palavras do pai: "É a minha liberdade - ouvi-te gritar na véspera da tua fuga." (2018, p. 43).

Outro feminino viés é apresentado em "Eu já tinha a minha bandeira", considerado um conto múltiplo, pois, além da temática feminina, aborda a condição do ilhéu, a maternidade e o racismo. Pensar a "América" como um lugar onde todos os sonhos são possíveis no pensamento da prima Tanha, cujo filho havia migrado e casado com uma "Americana. Mesmo da América. Não filha de cabo-verdianos, não. Filha de americanos" (2018, p. 66) e tinha duas filhas - "netas cada vez mais lindas e cada vez mais parecidas com a mãe, sua nora que era branca alva." (2018, p. 66) -, motivo de muita alegria e orgulho para a mãe cabo-verdiana até sua tão sonhada visita à casa do filho, na América. A avó é vítima da crueldade e racismo das netas, que chamam a polícia após elas destruírem tudo a sua volta e não compreenderem a língua da "avó crioula" e do próprio filho que, por não discordar da esposa e das filhas, pela repreensão feita às meninas, deixa a mãe partir para nunca mais vê-la. A dororidade (PIEDADE, 2018) da mulher e mãe negra é discutida de forma minuciosa pela autora. 
O quadro que compõe as narrativas sobre o arquipélago e a questão da insularidade, "São Nicolau, minha ternura brava", narra a visita dos emigrantes e visitantes, e a relação do ilhéu com a questão da chuva, uma constante no imaginário e na Literatura Cabo-verdiana. "Domingo como uma onda de liberdade", cujo "cais é a fronteira!" (2018, p.25) e "As estrelas do meu céu", onde as chuvas ganham o protagonismo, sobretudo quando os sentimentos, retratados na capa, na figura do cais, as dicotomias entre partir e ficar, campo e cidade, ganham corpo em situações extremas, como a ausência de chuva constante, que acaba influenciando na partida de muitos ilhéus para a cidade. "O campo devia ser uma coisa boa para se ter saudades, não para se conviver todos os dias na insegurança e no medo[...] Dias depois, estava de visita ao irmão para sondar as possibilidades de se mudar para junto dele e tentar a vida na cidade, quando choveu na ilha." (2018, p.46).

A chuva apresenta-se como elemento definitivo para que a protagonista permaneça no campo e continue a olhar cada gota de chuva como uma estrela do seu céu. Já no monólogo "O texto que não consigo escrever", Dina Salústio desabafa no papel os problemas enfrentados pela mulher. Tema tão caro à autora, e tão necessário, que a leva a pensar sobre a dificuldade de escrever acerca de determinados temas devido à intensidade com que esses temas a atravessam como mulher, mãe, profissional e escritora. Finalizando, "Condição de Ilhéu" e "Crónica da escravatura ou... os nossos avós estavam lá”, assim como "De um lado ou de outro", compõem o quadro teórico-crítico que completa a obra de Salústio. Neste último, a autora aborda a questão da escravidão, como memória a ser reconhecida e incorporada para a libertação das mentalidades e dos sujeitos, visto que essa temática, além de original na escrita da autora, também o é na Literatura Cabo-verdiana.

\section{REFERÊNCIAS}

PIEDADE, Vilma. Dororidade. São Paulo: Editora Nós, 2017.

SALÚSTIO, Dina. Filhos de Deus. Contos e monólogos. Cabo Verde: Biblioteca Nacional de Cabo Verde, 2018.

Recebido para avaliação em 31/10/20 Aprovado para publicação em 10/11/20

\section{NOTA}

1 Pesquisadora (PNPD) na Universidade Federal do Pará (UFPA). Doutora em Letras Vernáculas / Subárea - Literaturas Portuguesa e Africanas, pela Universidade Federal do Rio de Janeiro (UFRJ). Mestre em Estudos Literários / Subárea - Literatura Portuguesa e Literaturas Africanas de Língua Portuguesa, pela Universidade Federal Fluminense (UFF, 2013) e licenciada em Letras Português/Francês pela Fundação Universidade do Rio Grande (FURG, 2006). Meu interesse versa, principalmente, nos seguintes temas: gênero, bildungsroman feminino, memória, trauma e literatura produzida por escritoras africanas, afro-brasileiras e paraenses. Atualmente, integra o Grupo de Pesquisa "Escritas do corpo feminino” (UFRJ/UNILAB). Orcid id: https://orcid.org/0000-0002-8948-4886 